\title{
THE EFFECTIVENESS OF VIDEO AS A TUTORIAL LEARNING MEDIA IN MUHADHOROH SUBJECT
}

\author{
P-ISSN: 2089-4341 | E-ISSN: 2655-9633 \\ https://uia.e-journal.id/akademika/article/view/1088 \\ DOI: 10.34005/akademika.v9i02.1088
}

Submitted: 2020-10-22 Reviewed: 2020-11-3 Published: 2020-11-30

\author{
Agus Riyanto \\ agusriyanto105@gmail.com \\ STIKes Bhakti Husada Bengkulu- \\ Indonesia
}

\author{
Eva Yunani \\ evayunani@gmail.com \\ STIKes Bhakti Husada Bengkulu- \\ Indonesia
}

\begin{abstract}
The purpose of this research was to test the effectiveness of video media as a tutorial learning media by looking at the percentage value of the assessment of the sample. The study used a survey research method with a quantitative approach and samples came from students of SMP IT Istiqomah, data collection techniques used observations of the course of learning and questionnaires which aimed to get a picture of the effectiveness of using video tutorials with 20 statements containing positive and negative statements after conducting the survey holding lecture learning. The results showed that the range of the assessment score was $1.00-1.49$, getting a percentage of the unfavorable category was $0 \%$, the range of the assessment score was 1.50-2.49, getting the percentage in the fairly good category was $32.14 \%$, the range of the assessment score was 2, $50-3.49$ get a percentage in the good category is $57.14 \%$ and the range of the assessment score is $3.50-4.00$ getting the percentage in the very good category is $10.71 \%$, this shows that the assessment that video is the highest tutorial learning media at Good category and it can be concluded that the video as an effective tutorial learning media with an assessment score range of $2.50-4.49$. The results showed that the description of the video as a tutorial learning media in the effective category was used to complement learning tools as material for discussion, practice and could improve students' abilities, this was seen from the increased activity and creativity of teachers and students in participating in learning and this media was very effective in the online learning periode.
\end{abstract}

Keyword : video, effectiveness, tutorial, learning media

\begin{abstract}
Abstrak: Tujuan penelitian ini untuk menguji keefektifan media video sebagai media pembelajaran tutorial dengan melihat nilai persentase penilaian dari sampel. Penelitian menggunakan metode penelitian survey dengan pendekatan kuantitatif dan sampel berasal dari siswa-siswi SMP IT Istiqomah, teknik pengumpulan data menggunakan observasi terhadap jalannya pembelajaran dan angket yang bertujuan untuk mendapat gambaran keefektifan penggunaan video tutorial dengan 20 butir pernyataan mengandung pernyataan positif dan negatif setelah melakukan survei penyelenggaraan pembelajaran ceramah. Hasil penelitian menunjukkan rentang skor penilaian 1,00 - 1,49 mendapatkan presentase pada kategori kurang baik adalah $0 \%$, rentang skor penilaian 1,50 - 2,49 mendapatkan persentase pada kategori cukup baik adalah $32,14 \%$, rentang
\end{abstract}


skor penilaian 2,50 - 3,49 mendapatkan persentase pada kategori baik adalah 57,14\% dan rentang skor penilaian 3,50 - 4,00 mendapatkan persentase pada kategori sangat baik adalah 10,71\%, hal ini menunjukkan penilaian bahwa video sebagai media pembelajaran tutorial tertinggi pada kategori Baik serta dapat disimpulkan bahwa video sebagai media pembelajaran tutorial Efektif dengan rentang skor penilaian 2,50 - 4,49. Hasil penelitian didapatkan gambaran video sebagai media pembelajaran tutorial dalam kategori efektif digunakan untuk melengkapai sarana pembelajaran sebagai bahan diskusi, praktek dan dapat meningkatkan kemampuan siswa hal ini terlihat dari meningkatnya keaktifan serta kreatifitas guru dan siswa dalam mengikuti pembelajaran dan media ini sangat efektif di masa pembelajaran daring.

Kata Kunci : video, efektifitas, tutorial, media pembelajaran

\section{PENDAHULUAN}

Pandemi COVID 19 telah merubah semua tatanan kehidupan manusia secara keseluruhan, terutama dalam bidang pendidikan yang mengharuskan stageholder dapat cepat menyesuaikan diri terhadap kehidupan baru dalam segi pembelajaran. Metode dan Media pembelajaran konvensional dan metode pembelajaran yang telah berjalan diwajibkan untuk melakukan penyesuaian secara menyeluruh. Pemanfaatan dan memaksimalkan semua platform yang dapat digunakan dalam memudahkan serta memfasilitasi pembelajaran. Alternative pembelajaran yang popular adalah dengan fasilitas daring menggunakan berbagai macam platform media sosial yang tersedia serta dapat mudah di akses dan mudah digunakan (Dewi, 2020), (Eko Yulianto et al., 2020). Selain memberikan pembelajaran daring, metode pembelajaran yang dimanfaatkan juga disesuaikan dengan kondisi lingkungan yang ada, kota Bengkulu sebagian besar sudah terjangkau akses internet sehingga memudahkan proses pembelajaran daring namun terkendala dengan terbatasnya kuota internet masing-masing siswa maupun guru agar tetap terhubung. Alat bantu dan media pembelajaran yang dapat menciptakan proses belajar yang menyenangkan, menarik, interaktif dan efektif serta membantu siswa dalam memahami materi ajar sehingga tujuan pembelajaran dapat tercapai dengan baik sangat diperlukan dalam bidang pendidikan, dalam hal ini guru diharuskan untuk selalu berinovasi dan melakukan penyesuaian. Perubahan yang cepat menyebabkan persiapan untuk menghadapi berbagai perubahan Penelitian ini mengangkat video sebagai media tutorial dalam pembelajaran dikarenakan video (Batubara \& Batubara, 2020), (Wirasasmita \& Putra, 2018). Media pembelajaran merupakan salah satu teknologi yang dapat dimanfatkan sebagai media pembelajaran yaitu media video. Media video adalah seperangkat komponen atau media yang mampu menampilkan gambar sekaligus suara dalam waktu yang bersamaan (Bustanil et al., 2019). Video adalah sebuah perekaman, penyimpanan dan pengolahan gambar diam sehingga ia tampak seperti 
gambar bergerak (Ramadinata et al., 2020). Video berasal dari kata vidi atau visum yang berarti melihat atau mempunyai daya penglihatan (Fadhli, 2015), (Yuanta, 2020).

Permasalahan dalam pembelajaran ceramah adalah konsep menulis dan minat berkomunikasi lisan (Nurdiansyah \& R. Abdulrahman, 2020) Teacher Centered Learning telah banyak dilakukan modifikasi guna mengurangi pembelajaran yang bersifat satu arah antara lain dengan penggabungan beberapa metode pembelajaran tetapi metode pembelajaran tersebut masih dirasakan kurang berkembang atau belum dapat maksimal (Ramdhani, 2014), dijelaskan juga bahwa keunggulan video sebagai media pembelajaran mudah digunakan dan mampu menjelaskan konten dengan lebih nyata. Kelemahannya tidak interaktif (Batubara \& Ariani, 2016), Video dinilai efektif digunakan untuk jenjang siswa sekolah dasar karena ketiga kelebihan tersebut dapat memenuhi kebutuhan belajar siswa sekolah dasar yang berada pada fase operasional konkret (Hadi, 2017). Salah satu media pembelajaran yang sesuai untuk permasalahan tersebut adalah dengan mengembangkan media pembelajaran berbasis video (Hendriyani et al., 2018). Penggunaan video tutorial dalam penelitian ini bukan merupakan hasil riset dan pengembangan yang dilakukan oleh peneliti, tetapi memanfaatkan beberapa video tutorial yang telah ada dan tersedia sebagai bahan referensi dan rujukan, dengan banyaknya referensi dan rujukan video tutorial menjadikan siswa mempunyai banyak wawasan dan pengetahuan serta memperkaya gambaran siswa.

Banyak sekali inovasi pembelajaran yang diperkenalkan sebagai alat untuk belajar berbicara, salah satunya adalah teknologi modern. Dalam pembelajaran, banyak jenis teknologi modern yang diperkenalkan untuk membantu siswa dalam belajar berbicara, seperti laboraturium bahasa, video, satelit, internet, blog, kamus digital, dan lainnya. Teknologi modern tersebut bertujuan untuk meningkatkan kemampuan siswa dalam berbicara (Kuning, 2019). Pemanfaatan video sebagai media tutorial dalam pembelajaran bukan hanya memudahkan siswa dalam mendalami materi, tetapi juga memudahkan pengajar dalam membimbing secara langsung, ketika video tutorial ditayangkan maka pengajar dapat mendekati dan mengamati siswa sehingga waktu yang digunakan semakin efektif (Pritandhari \& Ratnawuri, 2015).

Hasil observasi yang dilakukan pada 18 Maret 2020 di SMP IT Istiqomah ditemukan hambatan dalam proses belajar mengajar, yaitu kurangnya pemanfaatan media pembelajaran dengan unsur perangkat lunak yang mendukung. Masih sedikitnya guru yang menggunakan komputer sebagai sarana belajar atau media pembelajaran. Guru masih menggunakan buku sebagai sumber belajar dan papan tulis sebagai media pembelajaran, hal ini membuat siswa merasa kurang tertarik dalam pembelajaran yang akhirnya membuat siswa mengalami kesulitan dalam pelajaran dan kurang memahami konsep ceramah yang diberikan oleh 
guru, dengan terjadinya pandemi menjadikan guru dan siswa diharuskan belajar secara daring dan mengoptimalkan sumber belajar daring untuk membantu dan memudahkan penyampaian materi.

\section{METODE}

Penelitian ini menggunakan metode survei dengan pendekatan kuantitatif (Nugroho, 2017), teknik sampling merupakan total sampel dengan sampel berasal dari siswa-siswi SMP IT Istiqomah Bengkulu berjumlah 28 siswa dan siswi. Teknik pengumpulan data menggunakan angket, penggunaan angket bertujuan untuk memperoleh gambaran tentang efektifitas video sebagai media pembelajaran tutorial. Angket terdiri dari 20 butir pernyataan mengandung pernyataan positif dan negatif yang telah diuji terlebih dahulu menggunakan uji validitas dan uji reliabilitas untuk mengetahui kehandalan instrumen.

Analisis data menggunakan deskriptif kuantitatif dengan skor setiap pernyataan positif $(+)$ yaitu 4 untuk sangat tepat, 3 untuk tepat, 2 untuk kurang tepat dan 1 untuk tidak tepat, kemudian untuk pernyataan negatif () adalah 1 untuk sangat tepat, 2 untuk tepat, 3 untuk kurang tepat dan 4 untuk tidak tepat.

Tabel 1. Skor Penilaian Kemampuan Ceramah

\begin{tabular}{lcc}
\hline \multicolumn{1}{c}{ Pilihan } & \multicolumn{2}{c}{ Skor } \\
\cline { 2 - 3 } & Pernyataan Positif & Pernyataan Negatif \\
\hline Sangat Tepat & 4 & 1 \\
\hline Tepat & 3 & 2 \\
\hline Kurang Tepat & 2 & 3 \\
\hline Tidak Tepat & 1 & 4 \\
\hline
\end{tabular}

Tabel 2. Kategori Perolehan Skor

\begin{tabular}{cc}
\hline Skor Rata-Rata & Kategori \\
\hline $1,00-1,49$ & Kurang Baik \\
\hline $1,50-2,49$ & Cukup Baik \\
\hline $2,50-3,49$ & Baik \\
\hline $3,50-4,00$ & Sangat Baik \\
\hline
\end{tabular}

Tabel 3. Kisi-Kisi Angket Kemampuan Ceramah

\begin{tabular}{cccc}
\hline \multirow{2}{*}{ Variabel } & \multirow{2}{*}{ Aspek } & \multicolumn{2}{c}{ Nomor } \\
\cline { 2 - 4 } & Materi & Positif & Negatif \\
\cline { 2 - 4 } Kemampuan & Gestur & 5,15 & 7 \\
\cline { 2 - 4 } Ceramah & Volume & 6,11 & 9,18 \\
\cline { 2 - 4 } & Ekspresi & $3,8,10$ & 12,13 \\
\cline { 2 - 4 } & Intonasi & 2,17 & 19,14 \\
\hline
\end{tabular}

Persentase aspek yang di amati dan pengkategorian menggunakan rumus 


$$
\text { Persentase }=\frac{\text { Skor yang diperoleh }}{\text { Jumlah skor maksimal }} \times 100 \%
$$

\section{HASIL}

Sejumlah hasil analisis data yang diperoleh dirangkum berdasarkan aspek kemampuan ceramah yang terdiri dari aspek materi, gesture, volume, ekspresi dan intonasi dan berdasarkan keseluruhan kriteria, digambarkan dalam tabel :

Tabel 4. Hasil Kemampuan Ceramah

\begin{tabular}{cccc}
\hline Kategori & Rentang Skor & Jumlah & Persentase \\
\hline Kurang Baik & $1,00-1,49$ & 0 & $0 \%$ \\
\hline Cukup Baik & $1,50-2,49$ & 9 & $32,14 \%$ \\
\hline Baik & $2,50-3,49$ & 16 & $57,14 \%$ \\
\hline Sangat Baik & $3,50-4,00$ & 3 & $10,71 \%$ \\
\hline & & 28 & $100 \%$ \\
\hline
\end{tabular}

Deskripsi dari tabel 4 menunjukkan dari 28 siswa tidak terdapat siswa dengan kategori kurang baik, terdapat 9 siswa dengan kategori cukup baik dengan rentang skor $1,50-2,49$, terdapat 16 siswa dengan kategori baik dengan rentang skor 2,50 - 3,49 dan terdapat 3 siswa dengan kategori Sangat Baik denga rentang skor 3,50 - 4,00.

\section{PEMBAHASAN}

Hasil analisis tersebut memberi gambaran keefektifan video sebagai media pembelajaran tutorial pada kategori baik sehingga dapat disimpulkan bahwa video dapat dimanfaatkan sebagai sarana melengkapi bahan rujukan pembelajaran, sejalan dengan beberapa penelitian sebelumnya yang menyatakan bahwa video sebagai media pembelajaran tutorial sangat membantu mengilustrasikan dan memberikan gambaran peristiwa yang bergerak, prosedur atau pun konsep yang abstrak dan bergerak (Pratiwi \& Puspito Hapsari, 2020), (Mandalika \& Syahril, 2020), (Batubara \& Batubara, 2020).

Keefektifan video tutorial untuk meningkatkan kemampuan berseramah siswa berada pada kategori cukup baik adalah 32,14\%, kategori baik adalah 57,14\% dan kategori sangat baik adalah 10,71\%, hal ini menggambarkan ada peningkatan kemampuan pada siswa dalam membawakan ceramah sesuai dengan definisi keefektifan yang berarti tepat penggunaan, hasil guna dan menunjang tujuan, maka disimpulkan bahwa penggunaan video sebagai media tutorial dalam meningkatkan kemampuan berceramah adalah efektif. Penggunaan video saat pembelajaran daring dirasakan sangat membantu (Batubara \& Batubara, 2020). Pemanfaatan video sebagai media tutorial efektif dalam 
meningkatkan kemampuan dikarenakan juga media pembelajaran video dapat dipelajari secara berulang kali dan berkelanjutan oleh siswa sehingga memudahkan siswa untuk lebih mendalami contoh serta memperbanyak referensinya (Batubara \& Ariani, 2016). Guru dituntut untuk mampu menyesuaikan dengan keadaan lingkungan sekolah, karakteristik siswa, pokok bahasan agar bisa menerapkanstrategi yang baik dan tepat digunakan untuk setiap kelas (Kristiyani \& Budiningsih, 2019)

\section{KESIMPULAN}

Berdasarkan data hasil penelitian maka disimpulkan bahwa video sebagai media pembelajaran tutorial pada saat ini dapat dikategorikan efektif digunakan untuk melengkapi sarana pembelajaran sebagai bahan diskusi, praktek dan dapat meningkatkan kemampuan siswa. Penelitian ini merupakan penelitian survey analitik yang hasilnya berdasarkan observasi dari peneliti, hal ini juga merupakan salah satu keterbatasan dari penelitian maka kedepannya diharapkan penelitian dapat dikembangkan dengan metode eksperimen

Berdasarkan hasil penelitian di SMP IT Istiqomah Bengkulu, maka guru diharapkan dapat meningkatkan kualitas mengajar yang maksimal dengan cara menggunakan media pembelajaran yang tepat agar siswa dapat lebih mudah mamahami materi pembelajaran yang disampaikan. Selain itu hendaknya siswa dapat meningkatkan keaktifan dan kreatifitas dalam mengikuti kegiatan pembelajaran sehingga dapat meningkatkan hasil kemampuan berceramah.

\section{DAFTAR PUSTAKA}

Batubara, H. H., \& Ariani, D. N. (2016). Pemanfaatan Video sebagai Media Pembelajaran Matematika SD/MI. Muallimuna : Jurnal Madrasah Ibtidaiyah. https://doi.org/10.31602/muallimuna.v2i1.741

Batubara, H. H., \& Batubara, D. S. (2020). Penggunaan Video Tutorial Untuk Mendukung Pembelajaran Daring di Masa Pandemi Virus Corona Muallimuna : Jurnal Madrasah Ibtidaiyah. https://doi.org/10.31602/muallimuna.v5i2.2950

Bustanil, M., Asrowi, \& Ardianto, D. T. (2019). Pengembangan Media Pembelajaran Interaktif Berbasis Video Tutorial Di Sekolah Menengah Kejuruan. JTP - Jurnal Teknologi Pendidikan.

Dewi, W. A. F. (2020). Dampak COVID-19 terhadap Implementasi

PembelajaDewi, W. A. F. (2020). Dampak COVID-19 terhadap Implementasi Pembelajaran Daring di Sekolah Dasar. Edukatif : Jurnal Ilmu Pendidikan https://doi.org/10.31004/edukatif.v2i1.89ran Daring di Sekolah Dasar.

Eko Yulianto, Putri Dwi Cahyani, \& Sofia Silvianita. (2020). Perbandingan Kehadiran Sosial dalam Pembelajaran Daring Menggunakan Whatsapp 
groupdan Webinar Zoom Berdasarkan Sudut Pandang Pembelajar Pada Masa Pandemic COVID-19. JARTIKA Jurnal Riset Teknologi Dan Inovasi

Pendidikan. https://doi.org/10.36765/jartika.v3i2.277

Fadhli, M. (2015). Pengembangan Media Pembelajaran Berbasis Video Kelas IV

Sekolah Dasar. Jurnal Dimensi Pendidikan Dan Pembelajaran.

https://doi.org/10.24269/dpp.v3i1.157

Hadi, S. (2017). Efektivitas Penggunaan Video Sebagai Media. Transformasi

Pendidikan Abad 21.

Hendriyani, Y., Effendi, H., \& Farell, G. (2018). Pelatihan Pengembangan Media

Pembelajaran Interaktif Berbasis ICT Bagi Guru-Guru Di SMP Negeri Di

Kecamatan Harau, Kabupaten Lima Puluh Kota. UNES Journal of

Community Service. https://doi.org/10.31933/ujcs.3.2.090-096.2018

Kristiyani, E., \& Budiningsih, I. (2019). Pengaruh Strategi Pembelajaran E-

learning dan Minat Belajar Terhadap Hasil Belajar Akuntansi. Akademika. https://doi.org/10.34005/akademika.v8i01.341

Kuning, D. S. (2019). Technology In Teaching Spreaking Skill. Journal of

English Education, Literature and Linguistics.

https://doi.org/10.31540/jeell.v2i1.243

Mandalika, M., \& Syahril, S. (2020). Pengembangan Media Pembelajaran

Berbasis Video Tutorial untuk Meningkatkan Efektifitas Pembelajaran pada

Mata Kuliah Tata Rias Pengantin Indonesia. INVOTEK: Jurnal Inovasi

Vokasional Dan Teknologi. https://doi.org/10.24036/invotek.v20i1.725

Nugroho, S. (2017). Metode Kuantitatif. In UNIB Press.

Nurdiansyah, A., \& R. Abdulrahman, T. (2020). The Use Of Instagram To

Develop Students Writing Ability. Akademika.

https://doi.org/10.34005/akademika.v9i01.808

Pratiwi, B., \& Puspito Hapsari, K. (2020). Analisis Kemampuan Berpikir Tingkat

Tinggi Melalui Pemanfaatan YouTube Sebagai Media Pembelajaran Bahasa

Indonesia. Jurnal Ilmiah Sekolah Dasar.

https://doi.org/10.23887/jisd.v4i2.24238

Pritandhari, M., \& Ratnawuri, T. (2015). Evaluasi Penggunaan Video Tutorial

Sebagai Media Pembelajaran Semester IV Progra Studi Pendidikan Ekonomi

Universitas Muhammadiyah Metro. PROMOSI (Jurnal Pendidikan Ekonomi). https://doi.org/10.24127/ja.v3i2.329

Ramadinata, I. P. S., Sudatha, I. G. W., \& Parmiti, D. P. (2020). Pengaruh Model

Pembelajaran Cycle 5E Berbantuan Media Video Terhadap Sikap Sosial.

Jurnal Penelitian Dan Pengembangan Pendidikan.

https://doi.org/10.23887/jppp.v4i2.27336

Ramdhani, M. A. (2014). Perbandingan Strategi Pembelajaran Teacher Centered

Learning Dengan Student Centered Learning Terhadap Hasil Belajar Pada

Mata Pelajaran Tarikh Siswa Kelas Viii Smp Muhammadiyah 4 Surakarta.

2014. 
Wirasasmita, R. H., \& Putra, Y. K. (2018). Pengembangan Media Pembelajaran Video Tutorial Interaktif menggunakan Aplikasi Camtasia Studio dan Macromedia Flash. EDUMATIC: Jurnal Pendidikan Informatika.

https://doi.org/10.29408/edumatic.v1i2.944

Yuanta, F. (2020). Pengembangan Media Video Pembelajaran Ilmu Pengetahuan Sosial pada Siswa Sekolah Dasar. Trapsila: Jurnal Pendidikan Dasar. 